\title{
PREPARATION OF HIGH PERFORMANCE ACTIVATED CHARCOAL FROM RICE STRAW FOR COSMETIC AND PHARMACEUTICAL APPLICATIONS
}

\author{
THANAWAT PATTANANANDECHAa, SUMONTHA RAMANGKOONa, BUSABAN SIRITHUNYALUGa,c, JIDAPHA \\ TINOI $^{\mathrm{b}}$, CHALERMPONG SAENJUM ${ }^{\mathrm{a}, \mathrm{c}^{*}}$
}

aDepartment of Pharmaceutical Sciences, Faculty of Pharmacy, Chiang Mai University, Chiang Mai, 50200 Thailand, bDepartment of Chemistry, Faculty of Sciences, Chiang Mai University, Chiang Mai, 50200 Thailand, cCluster of Excellence on Biodiversity-based Economics and Society (B. BES-CMU), Chiang Mai University, Chiang Mai, 50200 Thailand

Email: chalermpong.saenjum@gmail.com

Received: 03 Nov 2018, Revised and Accepted: 12 Dec 2018

\begin{abstract}
Objective: Rice straw is an agricultural waste material which has a negative impact on the environmental. This study's aim was to prepare highperformance rice straw activated charcoal (RSAC) for cosmetic and pharmaceutical applications using chemical activation technique.

Methods: Three cultivars of rice straw namely Dok Mali 105 (DM105), RD6 and Niaw San-Pah-Tawng were selected to determine the lignin content. The rice straw with the highest lignin content was selected to produce rice straw activated charcoal. The particle of size 20, 40 and 60 mesh was carbonized at $200,300,400,500$ and $600{ }^{\circ} \mathrm{C}$ for 1,2 , and $3 \mathrm{~h}$. The obtained charcoal with the highest iodine number was then refluxed using potassium hydroxide and phosphoric acid as an activating agent in the ratios of $1: 10 \mathrm{w} / \mathrm{v}$ at $70,80,90$, and $100^{\circ} \mathrm{C}$ for $2(\mathrm{KOH})$ and $3\left(\mathrm{H}_{3} \mathrm{PO}_{4}\right) \mathrm{h}$. The adsorption ability on iodine, methylene blue, acetaminophen, and aflatoxin $\mathrm{B}_{1}$ was investigated. Additionally, pore structure, pore size, and surface area were also determined relative to medical-grade activated charcoal.
\end{abstract}

Results: DM105 rice straw contains the highest amount of lignin with $24.3 \%$ w/w, followed by RD6 and Niaw San-Pah-Tawng, respectively. DM105 rice straw with particle size 60 mesh carbonized at $400{ }^{\circ} \mathrm{C}$ for $2 \mathrm{~h}(\mathrm{DM} 60 \mathrm{~T} 400 \mathrm{H} 2)$ demonstrated the highest iodine number. The activation step of DM60T400H2 using 1:10 w/v potassium hydroxide at 70 and $80^{\circ} \mathrm{C}$ for $2 \mathrm{~h}$ exhibited the highest iodine, methylene blue, acetaminophen, and aflatoxin $\mathrm{B}_{1}$ adsorption capacity. The scanning electron microscope (SEM) image and Brunauer-Emmett-Teller (BET) showed the microporous structure of obtained RSAC.

Conclusion: RSAC prepared from rice straw of DM105 has potential in cosmetic or pharmaceutical applications.

Keywords: Rice straw, Activated charcoal, Phosphoric acid, Potassium hydroxide, Cosmetic and pharmaceutical applications

(C) 2019 The Authors. Published by Innovare Academic Sciences Pvt Ltd. This is an open-access article under the CC BY license (http://creativecommons.org/licenses/by/4.0/) DOI: http://dx.doi.org/10.22159/ijap.2019v11i1.30637

\section{INTRODUCTION}

Activated charcoal has become one of the most technically important and widely used adsorbents because of its high adsorptive capacity [1-3]. It can be prepared by two methods: chemical and physical activation [4]. In 2005-2011, Thailand imported approximately 2983 million tons of activated charcoal per year [5]. Activated charcoal was used in industrial processes, drinking water filtration, gas purification, liquid chemicals, catalyst supports, wastewater treatment, sugar syrup purification, cosmetics, medicinal and pharmaceutical products [6, 7]. Activated charcoal has been reported to reduce low-density cholesterol (LDL), which can cause plaque buildup in the arteries while increasing high-density cholesterol (HDL) $[8,9]$. The combination of oral activated charcoal and a low protein diet effectively control the uremic symptoms in old end-stage renal disease patients [10]. Moreover, nanoporous activated charcoal has demonstrated an ability to remove proinflammatory cytokines from the blood [11]. Activated charcoal has been use for teeth whitening and clear skin treatment in the cosmetics industry. High porous activated charcoal helps draw toxins from pollution up and out of the skin [7]. Activated charcoal has efficacy in prevention of drug absorption when activated charcoal is administered soon after drug ingestion $[13,14]$. It was the best agent to reduce absorption of acetaminophen from a single trial [15].

In Thailand, half of the population is engaged in the agriculture sector, mostly cultivation of rice, which is a staple food of most Thai people [16]. The production of rice reaches around 30 million tons per year. A significant amount of rice straw approximately 25.65 million tons remains in the fields, and this quantity is increasing every year [17]. The open burning of rice straw after harvesting is a common practice for rice straw disposal and the preparation of land in cultivation areas. This activity has serious negative effects on the air quality, public health, and traffic $[2,18]$. Rice straw is one of the most abundant waste materials in the agricultural sector. Its chemical structure consists of cellulose (32-47\%), hemicellulose (19-27\%) and lignin (5-24\%) [19]. In the pyrolysis step, cellulose and hemicellulose make up the volatile fraction, whereas carbonized residue from lignin forms charcoal [6]. Consequently, the composition of rice straw is important in char creation and a higher amount of lignin will affect a higher yield of charcoal. Therefore, lignin is the main source for preparation of activated charcoal [20].

The demand for activated charcoal has grown in the various industries, especially in the medicinal, cosmetic, and pharmaceutical industries. This demand forces us to consider a large number of raw material obtainable for the production of activated charcoal. Thus, the aim of this research was to successfully produce high-quality rice straw activated charcoal for cosmetic and pharmaceutical applications.

\section{MATERIALS AND METHODS}

\section{Materials}

Dok Mali 105 (DM105), RD6, and Niaw San-Pah-Tawng rice straw samples were collected from the Chiang Mai Rice Research Center, Chiang Mai, Thailand on November 2015. The rice straw was cut into small pieces, washed and dried at $110{ }^{\circ} \mathrm{C}$ for $24 \mathrm{~h}$. Rice straw material with a moisture content lower than $5 \%$ were selected for the further experiment. The rice straw material was ground and sieved to collect particles of size 20,40, and 60 mesh. All solvents and chemicals used were either high-performance liquid chromatography (HPLC) grade or analytical grade and were purchased commercially from Sigma Chemical Company (St. Louis, MO), Fluka Chemical Company (Switzerland), and Merck (Darmstadt, Germany). 


\section{Methods}

\section{Determination of lignin content}

Lignin content was determined using the Klason method and the AOAC official method 973.18 with slight modifications by Averous and Digabel (2006) [10]. Briefly, rice straw material was hydrolyzed by $72 \% \mathrm{H}_{2} \mathrm{SO}_{4}$ and refluxed for $3 \mathrm{~h}$. Then, the sample was filtrated and washed until it becomes neutral. The residue was dried at $100{ }^{\circ} \mathrm{C}$ for $20 \mathrm{~h}$, cooled in a desiccator and weighed (P1). The residue was then transferred into a crucible and heated at $500{ }^{\circ} \mathrm{C}$ for $3.5 \mathrm{~h}$, cooled in a desiccator and weighted (P2). The lignin content was calculated using the following formula.

$$
\text { Lignin content }=\frac{P 1-P 2}{M}
$$

WhereP1 is the weight of the sample after drying at $100{ }^{\circ} \mathrm{C}, \mathrm{P} 2$ is the weight of the sample after heated at $500{ }^{\circ} \mathrm{C}$, and $\mathrm{M}$ is the weight of the dried sample.

\section{Carbonization step}

The highest lignin content was selected to go on to the carbonization step. The rice straw material was carbonized at 200,300,400,500, and $600^{\circ} \mathrm{C}$ in a furnace for 1,2 , and $3 \mathrm{~h}$. After carbonization, the obtained rice straw char (RSC) was cooled down to room temperature in a desiccator before being investigated for iodine and methylene blue adsorption, as well as being measured for pore structure by SEM.

\section{Activation step}

The highest iodine and methylene blue adsorption of obtained RSC was selected for the chemical activation step. The activation step was performed by reflux using $85 \% \mathrm{H}_{3} \mathrm{PO}_{4}$ and $85 \% \mathrm{KOH}$ as an activating agent in the refluxing ratios of $1: 8,1: 10,1: 15$, and 1:20 $\mathrm{w} / \mathrm{v}$ at $70,80,90$ and $100{ }^{\circ} \mathrm{C}$ for 1,2 , and $3 \mathrm{~h}$. Then, the obtained rice straw activated charcoal (RSAC) samples were washed with hot water to remove residual acid and base. The neutral RSAC samples were then dried at $110{ }^{\circ} \mathrm{C}$ for $24 \mathrm{~h}$ and cooled in a desiccator. The RSAC samples were measured for iodine, methylene blue, iron, zinc, acetaminophen, and aflatoxin adsorption. Additionally, pore structure was captured using SEM.

\section{Determination for iodine adsorption}

The iodine adsorption efficiency of RSC and RSAC samples were determined relative to a positive control, a commercial medicalgrade activated charcoal. The iodine number was determined according to the certified method of American Society for Testing and Materials (ASTM D4607-94) [14].

\section{Determination for methylene blue adsorption}

The methylene blue adsorption efficiency of RSC and RSAC samples were examined relative to a positive control; a commercial medicalgrade activated charcoal. The methylene blue number was determined according to the method of Japanese Industrial Standards Committee standard (JIS) [12].

\section{Determination for aflatoxin $B_{1}$ adsorption}

The aflatoxin $B_{1}$ adsorption of RSAC samples was carried out as per the method described by Stroka et al. (2000) [14] with some modifications. Briefly, $10 \mu \mathrm{g} / \mathrm{ml}$ of standard aflatoxin $\mathrm{B}_{1}$ solutions was added to $20 \mathrm{mg}$ of the RSAC samples. Then, the mixture was incubated in shacking incubator at $37^{\circ} \mathrm{C} 300 \mathrm{rpm}$ for $30 \mathrm{~min}$. The RSAC samples were separated from the solution using a syringe filter membrane. The residue of aflatoxin $\mathrm{B}_{1}$ was analyzed by Agilent 1200 HPLC couple with a fluorescence detector. The mobile phase consists of acetonitrile, methanol, and water in the ratio of 20:20:60 by volume with flow rate of $0.8 \mathrm{ml} / \mathrm{min}$. The RP-C18 Symmetry shield column ( 4.6 x $250 \mathrm{~mm}$ Waters Co., Ltd.) was used, excitation and emission wavelength were set at $365 \mathrm{~nm}$ and $450 \mathrm{~nm}$, respectively. Each sample was analyzed in triplicate.

\section{Determination for acetaminophen adsorption}

The adsorption efficiency of RSAC samples on acetaminophen was measured by slightly modifying the method of Rey-Mafull et al. (2014) [21] in simulated gastric fluid (SGF) at pH 1.2 and simulated intestinal fluid (SIF) pH 6.8. Briefly, acetaminophen was added to the SGF and SIF solutions reaching a concentration $200 \mu \mathrm{g} / \mathrm{ml}$. Then, 25 mg of RSAC samples were mixed with SGF and SIF solutions and incubated at $37{ }^{\circ} \mathrm{C} 100 \mathrm{rpm}$ for $30 \mathrm{~min}$ in a shacking incubator. The RSAC samples were removed using a syringe filter membrane. The residue of acetaminophen was measured by Agilent 1200 HPLC coupled with UV detector [15]. The mobile phase consists of acetonitrile and $0.1 \mathrm{M} \mathrm{KH}_{2} \mathrm{PO}_{4}$ in the ratio of $35: 65 \mathrm{v} / \mathrm{v}$ with a flow rate of $1.0 \mathrm{ml} / \mathrm{min}$. The separation was performed using RP-C18 Symmetry shield column, and the wavelength of the detector was set at $210 \mathrm{~nm}$. Each sample was analyzed in triplicate.

\section{Determination of pore structure}

The pore structure of selected RSAC samples was recorded by SEM (JEOL JSM-5910LV) at Science and Technology Service Center, Faculty of Science, Chiang Mai University.

\section{Determination of pore size and surface area}

Both of pore size and the surface of selected RSAC samples $(0.1000$ g) were taken and analyzed by a Surface Area Analyzer (Autosorb 1 Quantachrome, USA) using $\mathrm{N}_{2}$ as purge Gas.

\section{Statistical analysis}

All the results were expressed as a mean of three replicate \pm standard deviations (SD). All statistical analysis was conducted using SPSS (version 16 ). $P$ values $<0.05$ were significant.

\section{RESULTS AND DISCUSSION}

Three cultivars of rice straw namely DM105, RD6, and Niaw SanPah-Tawng were selected to determine the lignin content, and rice straw material with highest lignin content was selected for the material to be used in charcoal preparation. The lignin content of the three cultivars of rice straw is presented in table 1.

Table 1: Lignin contents of rice straw samples

\begin{tabular}{ll}
\hline Rice straw cultivars sample & Lignin content \\
\hline DM105 & $24.28 \pm 0.17^{\mathrm{a}}$ \\
RD 6 & $20.16 \pm 0.04^{\mathrm{b}}$ \\
Niaw San-Pah-Tawng & $18.87 \pm 0.04^{\mathrm{c}}$ \\
\hline
\end{tabular}

*all values were expressed as mean $\pm S D, n=3$, superscript letters show the significantly $(p<0.05)$ different from each other.

The results indicated that DM105 rice straw has a higher lignin content than RD6 and Niaw San-Pah-Tawng. It has been reported that the raw material with high contents of lignin produces a higher yield of charcoal and a higher amount of activated charcoal. Interestingly, lignin carbon has more pore volume than cellulose-delivered carbon [4]. According to the determined lignin content, DM105 rice straw was then selected to prepare the RSC and RSAC.
Iodine and methylene adsorption values of RSC samples are presented in table 2. The results demonstrated that charcoal obtained from particle size 60 mesh, carbonized at $400{ }^{\circ} \mathrm{C}$ for $2 \mathrm{~h}$ (DM60T400H2) exhibited the highest iodine and methylene blue adsorption by a significant margin. The carbonization process at 500 and $600{ }^{\circ} \mathrm{C}$ was over the carbonization temperature for rice straw, while the carbonization process at $200{ }^{\circ} \mathrm{C}$ was under the carbonization temperature for rice straw. The results revealed that 
iodine adsorption depends on carbonization temperature, carbonization time and particle size. The RSC samples obtained from 60 mesh (180-250 micron) particle size exhibited higher iodine adsorption values than those obtained from 40 mesh (250-425 micron) and 20 mesh (425-850 micron) particle size. Generally, the rice straw consists of $32-47 \%$ cellulose, $19-27 \%$ hemicellulose and $5-24 \%$ lignin. In this study, DM105 rice straw contains $24.3 \%$ lignin. Mohamed et al. (2013) [7] reported that a higher amount of lignin is necessary to develop more abundant pore structure. Our results demonstrated that the carbonization temperature at 300 and $400{ }^{\circ} \mathrm{C}$ is optimum for cellulose and hemicellulose decomposition in rice straw, leading to an increase of porosity and surface area. The DM60T400H2 was then activated with $\mathrm{KOH}$ and $\mathrm{H}_{3} \mathrm{PO}_{4}$. The iodine and methylene adsorption of obtained RSAC samples activated by $1: 10 \mathrm{w} / \mathrm{v}$ of $\mathrm{H}_{3} \mathrm{PO}_{4}$ and $\mathrm{KOH}$ at $70,80,90$, and $100^{\circ} \mathrm{C}$ are showed in table 3 .

Table 2: \% yield and an iodine number of RSC samples

\begin{tabular}{|c|c|c|c|c|c|}
\hline \multirow[t]{2}{*}{ Sample code } & \multirow{2}{*}{$\begin{array}{l}\text { Particle size } \\
(\mu \mathrm{m})\end{array}$} & \multicolumn{2}{|c|}{ Carbonization } & \multirow{2}{*}{$\begin{array}{l}\text { Iodine number } \\
\text { (mg/g) }\end{array}$} & \multirow[t]{2}{*}{ \%Yield } \\
\hline & & Temp $\left({ }^{\circ} \mathrm{C}\right)$ & Time (h) & & \\
\hline DM60T300H2 & $180-250$ & 300 & 2 & $28 \pm 0.35^{j}$ & 47.83 \\
\hline DM60T300H3 & & & 3 & $31 \pm 0.32^{\mathrm{i}}$ & 52.04 \\
\hline DM60T400H1 & & 400 & 1 & $88 \pm 0.18^{c}$ & 42.33 \\
\hline DM60T400H2 & & & 2 & $158 \pm 0.47^{a}$ & 40.78 \\
\hline DM60T400H3 & & & 3 & $77 \pm 0.27^{\mathrm{d}}$ & 36.44 \\
\hline DM40T300H2 & $250-425$ & 300 & 2 & $13 \pm 0.37 \mathrm{~m}$ & 47.01 \\
\hline DM40T300H3 & & & 3 & $17 \pm 0.23^{\mathrm{k}}$ & 45.75 \\
\hline DM40T400H1 & & 400 & 1 & $79 \pm 0.33^{\mathrm{d}}$ & 42.13 \\
\hline DM40T400H2 & & & 2 & $48 \pm 0.27^{f}$ & 38.67 \\
\hline DM40T400H3 & & & 3 & $90 \pm 0.32^{\mathrm{b}}$ & 29.27 \\
\hline DM20T300H2 & $425-850$ & 300 & 2 & $11 \pm 0.35^{\mathrm{n}}$ & 25.31 \\
\hline DM20T300H3 & & & 3 & $16 \pm 0.40^{1}$ & 20.11 \\
\hline DM20T400H1 & & 400 & 1 & $38 \pm 0.43^{\mathrm{h}}$ & 17.48 \\
\hline DM20T400H2 & & & 2 & $45 \pm 0.21^{g}$ & 15.90 \\
\hline DM20T400H3 & & & 3 & $37 \pm 0.37^{\mathrm{h}}$ & 14.37 \\
\hline
\end{tabular}

*all values were expressed as mean $\pm S D, n=3$, superscript letters show the significantly $(\mathrm{p}<0.05)$ different from each other.

Table 3: The iodine and methylene blue number of RSAC samples

\begin{tabular}{|c|c|c|c|c|}
\hline \multirow{2}{*}{$\begin{array}{l}\text { Activation } \\
\text { Temperatures }\left({ }^{\circ} \mathrm{C}\right)\end{array}$} & \multicolumn{2}{|c|}{ Iodine number (mg/g) } & \multicolumn{2}{|c|}{ Methylene blue number (mg/g) } \\
\hline & $\mathrm{H}_{3} \mathrm{PO}_{4}$ & КОH & $\mathrm{H}_{3} \mathrm{PO}_{4}$ & KOH \\
\hline 70 & $600 \pm 2.39 \mathrm{~g}$ & $950 \pm 4.41^{b}$ & $60 \pm 1.43^{\mathrm{de}}$ & $63 \pm 1.08^{\mathrm{d}}$ \\
\hline 80 & $646 \pm 3.62^{f}$ & $933 \pm 3.04^{c}$ & $57 \pm 1.12^{\mathrm{e}}$ & $109 \pm 2.14^{b}$ \\
\hline 90 & $532 \pm 3.77^{h}$ & $855 \pm 4.07 \mathrm{e}$ & $59 \pm 2.10^{\text {de }}$ & $46 \pm 1.26^{\mathrm{f}}$ \\
\hline 100 & $374 \pm 4.22^{j}$ & $924 \pm 3.53^{\mathrm{d}}$ & $65 \pm 1.14^{c}$ & $62 \pm 1.39 \mathrm{~d}$ \\
\hline DM60T400H2 & $158 \pm 0.07 \mathrm{k}$ & & $36 \pm 1.08^{f}$ & \\
\hline Medical-grade activated charcoal & $1009 \pm 0.39 a$ & & $359 \pm 0.98^{a}$ & \\
\hline
\end{tabular}

*all values were expressed as mean $\pm S D, n=3$, superscript letters show the significantly $(p<0.05)$ different from each other.

Table 3 shows that RSAC samples activated by reflux using KOH in the ratio of $1: 10 \mathrm{w} / \mathrm{v}$ as an activating agent at $70^{\circ} \mathrm{C}$ for $2 \mathrm{~h}$ exhibited highest iodine adsorption values, while the RSAC sample activated at $80{ }^{\circ} \mathrm{C}$ demonstrated the highest methylene blue adsorption value. The activation of RSC samples using $\mathrm{KOH}$ and $\mathrm{H}_{3} \mathrm{PO}_{4}$ increased the surface area of RSC due to the increase of iodine and methylene blue numbers. The iodine number is directly correlated with the microporous structure (values $>0$ to $20 \AA$, or up to $2 \mathrm{~nm}$ ) by adsorption of iodine from the solution and it is used as an indication of the total surface area $[22,23]$. Sorbents with higher iodine number perform better in removing small sized contaminants. It is the most fundamental parameter used to characterize the performance of activated charcoal [24]. Methylene blue contributes to the mesoporous prediction [25]. The RSAC samples activated by $\mathrm{KOH}$ and $\mathrm{H}_{3} \mathrm{PO}_{4}$ that exhibited a high iodine number might be composed of microporous structure more than of mesoporous structure.

Aflatoxins are derivative of difurocoumarin, synthesized by various toxigenic species of Aspergillus. Chemically, aflatoxins are difurocoumarin and classified into two main groups. The first group includes difurocoumarolactone series of aflatoxin $G_{1}$ and $G_{2}$, while the other is the difurocoumarocyclopentenone series containing aflatoxin $\mathrm{B}_{1}, \mathrm{~B}_{2}, \mathrm{~B}_{2} \mathrm{~A}, \mathrm{M}_{1}, \mathrm{M}_{2}, \mathrm{M}_{2} \mathrm{~A}$ and aflatoxicol [26]. Aflatoxin $\mathrm{B}_{1}$ $\left(\mathrm{C}_{17} \mathrm{H}_{12} \mathrm{O}_{6}\right)$ is a common contaminant in a variety of foods including peanuts, dried chili, corn, and other grains as well as animal feeds. Aflatoxin $\mathrm{B}_{1}$ is considered the most toxic aflatoxin and it is commonly implicated as inducing hepatocellular carcinoma in humans [27]. The adsorption ability of RSAC samples on aflatoxin $B_{1}$ are shown in table 4 .

Table 4: The adsorption ability of RSAC samples on aflatoxin $B_{1}$

\begin{tabular}{|c|c|c|c|c|}
\hline \multirow[t]{2}{*}{ Activation temperatures $\left({ }^{\circ} \mathrm{C}\right)$} & \multicolumn{2}{|c|}{ \% Adsorption } & \multicolumn{2}{|c|}{ Adsorption capacity ( $\mu$ g aflatoxin $B_{1} / g$ samples } \\
\hline & $\mathrm{H}_{3} \mathrm{PO}_{4}$ & KOH & $\mathrm{H}_{3} \mathrm{PO}_{4}$ & KOH \\
\hline 70 & $66.89 \pm 0.42^{\mathrm{e}}$ & $71.35 \pm 0.48^{\mathrm{c}}$ & $0.6675 \pm 0.0090^{\mathrm{E}}$ & $0.7217 \pm 0.0123^{\mathrm{C}}$ \\
\hline 80 & $64.79 \pm 0.32^{f}$ & $80.67 \pm 0.54^{\mathrm{b}}$ & $0.6465 \pm 0.0095^{\mathrm{F}}$ & $0.8136 \pm 0.0137$ в \\
\hline 90 & $65.47 \pm 0.37 \mathrm{f}$ & $67.66 \pm 0.37$ de & $0.6533 \pm 0.0074 \mathrm{~F}$ & $0.6752 \pm 0.0095^{\mathrm{DE}}$ \\
\hline 100 & $71.01 \pm 0.39 \mathrm{c}$ & $68.30 \pm 0.43^{\mathrm{d}}$ & $0.7086 \pm 0.0088^{\mathrm{C}}$ & $0.6825 \pm 0.0087 \mathrm{D}$ \\
\hline DM60T400H2 & $33.58 \pm 0.37 \mathrm{~g}$ & & $0.3562 \pm 0.0089 \mathrm{G}$ & \\
\hline Medical-grade activated charcoal & $82.54 \pm 0.22^{\mathrm{a}}$ & & $0.8603 \pm 0.0064^{\mathrm{A}}$ & \\
\hline
\end{tabular}

*all values were expressed as mean $\pm S D, n=3$, superscript letters show the significantly $(\mathrm{p}<0.05)$ different from each other. 
All of the RSAC samples activated by $\mathrm{H}_{3} \mathrm{PO}_{4}$ and $\mathrm{KOH}$ exhibited higher aflatoxin $\mathrm{B}_{1}$ adsorption capacity than those of RSC. RSAC samples activated by $\mathrm{KOH}$ revealed higher aflatoxin $\mathrm{B}_{1}$ adsorption capacity than those activated by $\mathrm{H}_{3} \mathrm{PO}_{4}$. The RSAC sample activated by $1: 10 \mathrm{w} / \mathrm{v} \mathrm{KOH}$ at $80{ }^{\circ} \mathrm{C}$ for $2 \mathrm{~h}$ showed the highest aflatoxin $\mathrm{B}_{1}$ adsorption capacity but lower than those of medical-grade activated charcoal. The results corresponded to the report of Galvano et al. (1996) [28], which reported that 13 experimental activated charcoal samples prepared from natural waste biomass and 4 commercial activated charcoal samples exhibited in vitro aflatoxin $\mathrm{B}_{1}$ adsorption abilities ranging from $44.47 \%$ to $99.82 \%$. In addition, mesopores (i.d. from 20 to $500 \AA$ or 2.0 to $50.0 \mathrm{~nm}$ ) must be directly involved in aflatoxin $\mathrm{B}_{1}$ adsorption and are able to increase adsorption ability because of a better fit to the aflatoxin $B_{1}$ molecule. On the contrary, a microporous structure (i.d. $<20 \AA \AA$ or $2.0 \mathrm{~nm}$ ) could hinder the diffusion of the aflatoxin $\mathrm{B}_{1}$ molecules inside the activated charcoal and decrease the adsorption ability.

The acetaminophen (N-acetyl-p-aminophenol, $\mathrm{C}_{8} \mathrm{H}_{9} \mathrm{NO}_{2}$ ) is a drug with analgesic properties. An overdose of acetaminophen induces hepatic injury and subsequent hepatic failure [29]. The adsorption capacity of RSAC samples on acetaminophen adsorption was evaluated in SGF $(\mathrm{pH}$ 1.2) and SIF $(\mathrm{pH}$ 6.8). The results demonstrated that most of RSAC samples exhibited a higher acetaminophen adsorption capacity than those of RSC. The RSAC samples activated by $\mathrm{KOH}$ showed a potential for acetaminophen adsorption capacity in both of SGF and SIF while the RSAC samples activated by $\mathrm{H}_{3} \mathrm{PO}_{4}$ exhibited good acetaminophen adsorption in only SIF. The acetaminophen adsorption capacity of RSAC samples are shown in table 5 .

Table 5: The adsorption capacity of RSAC samples on acetaminophen

\begin{tabular}{|c|c|c|c|c|}
\hline \multirow[t]{2}{*}{$\begin{array}{l}\text { Activation } \\
\text { Temperatures }\left({ }^{\circ} \mathrm{C}\right)\end{array}$} & \multicolumn{2}{|c|}{$\begin{array}{l}\text { Adsorption capacity in SGF (g acetaminophen/g } \\
\text { samples) }\end{array}$} & \multicolumn{2}{|c|}{$\begin{array}{l}\text { Adsorption capacity in SIF (g acetaminophen/g } \\
\text { samples) }\end{array}$} \\
\hline & $\mathrm{H}_{3} \mathrm{PO}_{4}$ & KOH & $\mathrm{H}_{3} \mathrm{PO}_{4}$ & KOH \\
\hline 70 & $0.0298 \pm 0.0015^{f}$ & $0.2153 \pm 0.0045^{b}$ & $0.2065 \pm 0.0062^{\mathrm{B}}$ & $0.1971 \pm 0.0047^{B}$ \\
\hline 80 & $0.0338 \pm 0.0019 \mathrm{e}$ & $0.1830 \pm 0.0056^{c}$ & $0.2066 \pm 0.0055^{B}$ & $0.1503 \pm 0.0052^{\mathrm{E}}$ \\
\hline 90 & $0.0113 \pm 0.0022^{\mathrm{gh}}$ & $0.1608 \pm 0.0064^{\mathrm{d}}$ & $0.1769 \pm 0.0063^{\mathrm{D}}$ & $0.1271 \pm 0.0068^{\mathrm{G}}$ \\
\hline 100 & $0.0101 \pm 0.0018^{\mathrm{h}}$ & $0.1739 \pm 0.0059^{\mathrm{cd}}$ & $0.1308 \pm 0.0058^{\mathrm{F}}$ & $0.1448 \pm 0.0057^{\mathrm{E}}$ \\
\hline DM60T400H2 & $0.0156 \pm 0.0021^{\mathrm{g}}$ & & $0.0748 \pm 0.0045^{\mathrm{H}}$ & \\
\hline $\begin{array}{l}\text { Medical-grade activated } \\
\text { charcoal }\end{array}$ & $0.2753 \pm 0.0039^{a}$ & & $0.4033 \pm 0.0044^{\mathrm{A}}$ & \\
\hline
\end{tabular}

*all values were expressed as mean $\pm S D, n=3$, superscript letters show the significantly $(p<0.05)$ different from each other.

Fig. 1 explains the morphology of obtained RSAC from reflux using $\mathrm{H}_{3} \mathrm{PO}_{4}$ and $\mathrm{KOH}$ as an activating agent at 70 and $80^{\circ} \mathrm{C}$. It was found
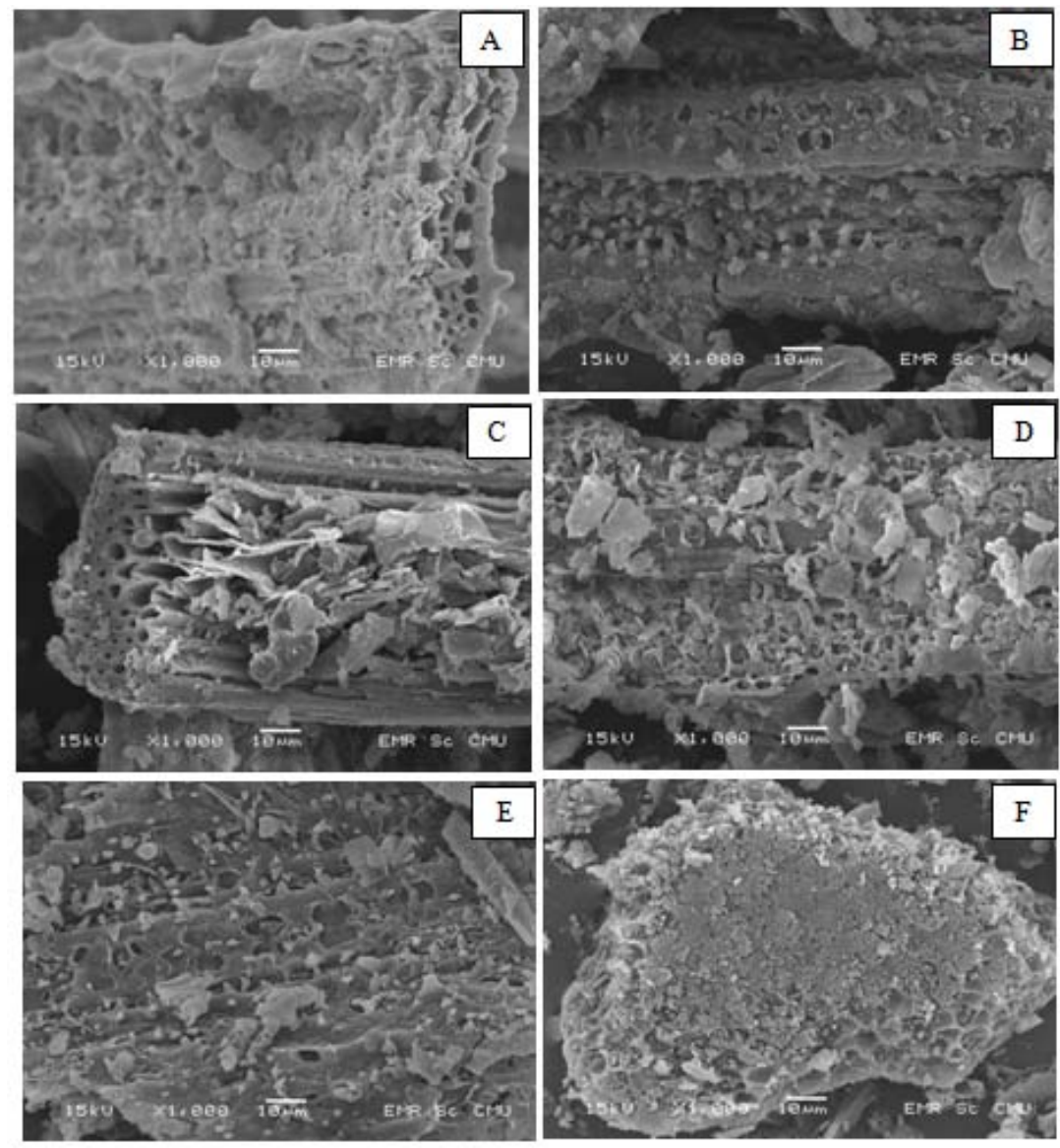

Fig. 1: SEM micrograph of the RSC and RSAC which A: DM60T400H2, B: RSAC activated by $\mathrm{H}_{3} \mathrm{PO}_{4}$ at $70{ }^{\circ} \mathrm{C}, \mathrm{C}: \mathrm{RSAC}$ activated by $\mathrm{H}_{3} \mathrm{PO}_{4}$ at 80 ${ }^{\circ} \mathrm{C}$, D: RSAC activated by $\mathrm{KOH}$ at $70^{\circ} \mathrm{C}$, E: RSAC activated by $\mathrm{KOH}$ at $80^{\circ} \mathrm{C}$, and F: Medical-grade activated charcoal 
The SEM micrograph of the RSC is shown in fig. 1A. It was found that the morphology of obtained charcoal looked like a honeycomb. This can be explained by the fact that the components and inorganic matters of rice straw decomposed and the porous structure was formed during the carbonization process whereas the lignin walls did not modify the pores. Fig. 1B and $1 \mathrm{C}$ showed the morphology of obtained RSAC from reflux using $\mathrm{H}_{3} \mathrm{PO}_{4}$ as an activating agent. It was found that at $80^{\circ} \mathrm{C}$, the inner part of RSAC created a new pore structure. Fig. 1D and 1E show the morphology of obtained RSAC from reflux using $\mathrm{KOH}$ as an activating agent. The results indicated that the lignin wall of obtained RSAC formed the new pore structure at 70 and $80{ }^{\circ} \mathrm{C}$. In addition, the average pore size of obtained RSAC in both $\mathrm{KOH}$ and $\mathrm{H}_{3} \mathrm{PO}_{4}$ activation demonstrated that it is composed of micropore structure (table 6) which correspond to the results of iodine adsorption. The results indicated that $\mathrm{KOH}$ treatment leads to a higher surface area than $\mathrm{H}_{3} \mathrm{PO}_{4}$ treatment. The reaction mechanism of $\mathrm{KOH}$ and carbon is a well-established activation method for producing porous activated charcoal materials [30]. A pore structure with the resultant high surface area is formed during $\mathrm{KOH}$ activation. It is suggested here that during $\mathrm{KOH}$ activation, the chemical reaction between $\mathrm{KOH}$ and carbon proceeds as $6 \mathrm{KOH}+2 \mathrm{C}=$ $2 \mathrm{~K}+3 \mathrm{H}_{2}+2 \mathrm{~K}_{2} \mathrm{CO}_{3}$; following either decomposition of $\mathrm{K}_{2} \mathrm{CO}_{3}$ or reaction of $\mathrm{K} / \mathrm{K}_{2} \mathrm{CO}_{3} / \mathrm{CO}_{2}$ with carbon, the production of $\mathrm{H}_{2}$ will potentially open up the pores [31].

Table 6: Pore size and surface area of RSAC samples

\begin{tabular}{|c|c|c|c|c|}
\hline \multirow[t]{2}{*}{ Activation temperatures $\left({ }^{\circ} \mathrm{C}\right)$} & \multicolumn{2}{|c|}{ Pore size $(\AA)$} & \multicolumn{2}{|c|}{ Surface area $\left(\mathrm{m}^{2} / \mathrm{g}\right)$} \\
\hline & $\mathrm{H}_{3} \mathrm{PO}_{4}$ & КОH & $\mathrm{H}_{3} \mathrm{PO}_{4}$ & КОН \\
\hline 70 & 11.65 & 9.07 & 642.86 & 952.72 \\
\hline 80 & 10.54 & 8.99 & 715.32 & 983.08 \\
\hline 90 & 13.32 & 11.29 & 487.64 & 759.28 \\
\hline 100 & 14.27 & 9.23 & 550.49 & 875.10 \\
\hline DM60T400H2 & 8.39 & & 272.49 & \\
\hline Medical-grade activated charcoal & 103.52 & & 1219.52 & \\
\hline
\end{tabular}

\section{CONCLUSION}

DM105 rice straw of particle size 60 mesh carbonized at $400{ }^{\circ} \mathrm{C}$ for 2 $h$ could affect the physicochemical properties of obtained RSC. The chemical activation by reflux using $\mathrm{KOH}$ as an activating agent in ratio $1: 10$ at 70 and $80{ }^{\circ} \mathrm{C}$ was more efficient in producing RSAC which exerted the potential to be used for cosmetic or pharmaceutical applications.

\section{ACKNOWLEDGMENT}

Authors would like to acknowledge financial support from Agricultural Research Development Agency (Public Organization) and also supported by Postdoctoral fellowship granted by Chiang Mai University.

\section{AUTHORS CONTRIBUTIONS}

All the author contributed equally

\section{CONFLICT OF INTERESTS}

Declared none

\section{REFERENCES}

1. Karthick SP, Radha KV. Equilibrium, isotherm, kinetic and thermodynamic adsorption studies of tetracycline hydrochloride onto commercial grade granular activated carbon. Int J Pharm Pharm Sci 2014;7:42-51.

2. Ramangkoon S, Saenjum C, Sirithunyalug B. Preparation of rice straw activated charcoal by 2-step $\mathrm{H}_{3} \mathrm{PO}_{4}$ activation. Int $\mathrm{J}$ Pharm Pharm Sci 2016;8:218-21.

3. Hassen JH, Ayfan AH, Farhan YM. Spectroscopic evaluation of activated charcoal as a poison antidote for gliclazide drug. Asian J Pharm Clin Res 2018;11:140-3.

4. Ioannidou O, Zabaniotou A. Agricultural residues as precursors for activated carbon production-a review. Renew Sust Energy Rev 2007;11:1966-2005.

5. Index Mundi. Thailand yearly imports in us dollars-activated nat. min. prods. other than of activated carbon; animal black, in; 2005-2011. Available from: http://www.indexmundi.com/ trade/imports/?commodity=380290andcountry=th. [Last accessed on 30 Sep 30].

6. Mohamed AR, Mohammadi M, Darzi GN. Preparation of carbon molecular sieve from lignocellulosic biomass: a review. Renewable Sustainable Energy Rev 2010;14:1591-9.

7. Mohamad Nor N, Lau LC, Lee KT, Mohamed AR. Synthesis of activated carbon from lignocellulosic biomass and its applications in air pollution control-a review. J Environ Chem Ecotoxicol 2013;1:658-66.
8. Cooney DO. Activated charcoal in medical applications. Marcel Dekker. New York; 1995.

9. Roy GM. Activated carbon applications in the food and pharmaceutical industries. U. S. A. Technomic publishing; 1995.

10. Averous L, Le Digabel F. Properties of biocomposites based on lignocellulosic fillers. Carbohydr Polym 2006;66:480-93.

11. American Standard of testing Material. Standard test method for Determination of Iodine Number of Activated Carbon ASTM D 4607-94; 1995.

12. Japanese IND. Standard committee. JIS, K 1426; 1958.

13. Karnib M, Kabbani A, Holail H, Olama Z. Heavy metals removal using activated carbon, silica and silica activated carbon composite. Energy Procedia 2014;50:113-20.

14. Stroka J, Ankalam E, Jorissen U, Gilbert J. Immunoaffinity column cleanup with liquid chromatography using post-column bromination for determination of aflatoxins in peanut butter, pistachio paste, fig past, paprika powder. Collaborative study. J Assoc Anal Chem Inter 2000;83:320-40.

15. Suresh P, Shyam LP. In vitro adsorption studies of paracetamol to an activated charcoal capsule, powder, and suspension. Open Toxicol J 2008;2:22-5.

16. Settharaksa S, Madaka F, Charkree K, Charoenchai L. The study of anti-inflammatory and antioxidant activity in cold press rice bran oil from rice in Thailand. Int J Pharm Pharm Sci 2014;6:428-31.

17. Department of Alternative Energy Development and Efficiency (DEDE) [Internet]. Potential biomass in Thailand. 2552 Available from: http://www.dede.go.th/dede/index.php? option=com_contentandview $=$ articleandid $=130: 2010-05-07$ $08-10-57$ andcatid $=58: 2010-04-06-09-19-36$ anditemid $=68$. [Last accessed on 10 Oct 2014].

18. El-Hendawy A-NA. Surface and adsorptive properties of carbons prepared from biomass. Appl Surf Sci 2005;252:287-95.

19. Binod P, Sindhu R, Singhania RR, Vikram S, Devi L, Nagalakshmi $\mathrm{S}$, et al. Bioethanol production from rice straw: An overview. Bioresour Technol 2010;101:4767-74.

20. Suhas, Carrott PJM, Ribeiro Carrott MML. Lignin-from natural adsorbent to activated carbon: a review. Bioresour Technol 2007;98:2301-12.

21. Rey Mafull CA, Tacoronte JE, Garcia R, Tobella J, Llopiz JC, Iglesias $\mathrm{A}$, et al. Comparative study of the adsorption of acetaminophen on activated carbons in simulated gastric fluid. Springer Plus 2014;3:48.

22. Itodo AU, Abdulrahman FW, Hassan LG, Maigandi SA, Itodo HU. Applications of methylene blue and iodine adsorption in the measurement of specific surface area by four acid and salttreated activated carbon. NY Sci J 2011;3:25-33.

23. Nunes CA, Guerreiro MC. Estimation of surface area and pore volume of activated carbons by methylene blue and iodine numbers. Quim Nova 2011;34:472-6. 
24. Aziza A, Odiakosa A, Nwajei G, Orodu V. Modification and characterization of activated carbon derived from Bumper sawdust and disk sawdust to remove lead (II) and cadmium (II) effluent water. CSN Conference proceeding. Chem Soc Nigeria 2008. p. 235-43.

25. Yan C, Wang C, Yao J, Zhang L, Liu X. Adsorption of methylene blue on mesoporous carbons prepared using acid-and alkalinetreated zeolite X as the template. Colloids Surf A 2009;333:115-9.

26. Binder EM. Managing the risk of mycotoxins in modern feed production. Anim Feed Sci Technol 2007;133:149-66.

27. Azab RM, Tawakkol WM, Hamad ARM, Abou-Elmagd MK, ElAgrab HM, Refai MK. Detection and estimation of aflatoxin B1 in feeds and its biodegradation by bacteria and fungi. Egypt J Nat Toxins 2005;2:39-56.
28. Galvano F, Pietri A, Fallico B, Bertuzzi T, ScirÈ S, Galvano M, et al. Activated carbons: in vitro affinity for aflatoxin $\mathrm{B} 1$ and relation of adsorption ability to physicochemical parameters. J Food Prot 1996;59:545-50.

29. Jaeschke H, Xie Y, McGill M. Acetaminophen-induced liver injury: from animal model to humans. J Clin Transl Hepatol 2014;2:153-61.

30. Viswanathan B, Indra Neel P, Varadarajan T. Method of activation and specific application of carbon material. Chennai: Indian Institute of Technology Madras; 2009.

31. Hossain MZ, Wu W, Zu WZ, Chowdhury MBI, Jhawr AK, Machin D, et al. High-surface-area mesoporeous activated carbon from hemp bast fiber using hydrothermal processing. J Carbon $\mathrm{R}$ 2018;4:1-15. 